\title{
The Interpretation of The Great Gatsby from the Perspective of Existentialism
}

\author{
Chang Qing, Li Shuhua \\ School of Foreign Language, Anshan Normal University, Anshan, China \\ Email: 1229316058@qq.com
}

\begin{abstract}
Scott Fitzgerald, American writer, is the spokesman of the "Jazz Age" and the representative writer of the "lost generation" in the 1920s. His masterpiece The Great Gatsby leaves an impressive mark in the history of American literature. The paper tries to analyze the protagonist Gatsby from the perspective of existentialism through the close reading. The human beings can be allowed and respected by choosing to live a free and wonderful life in order to confront the ugly and weird universe, however, they have to accept its consequence afterwards. To study the work from the view of existentialism, people can figure out how to realize their self-value and to live a manful life.
\end{abstract}

Keywords-Existentialism; Self-value; Absurdity; Choice of freedom

\section{INTRODUCTION}

Scott Fitzgerald(1896-1940), one of the best novelists in the United States in the 20th century, was born in an uppermiddle-class family in St Paul, Minnesota, however, at that moment the financial situation of the family was not promising. He went to the well-known aristocratic university locating on the East of the United States with the help of his rich relatives when he was eighteen. The declining family background situation left him a great deal of pressure when he was surrounded by the people from rich families. Fitzgerald had an ambitious father who kept encouraging him to work hard to be famous so that the family could regain its past glory. Struggling to erase his poor financial background and comfort his demanding father, Fitzgerald lost his health and was dropped out of the university at last, and joined in the army in 1917. He was busy training in the army, however, he kept writing when he was free. It was also in the army that he met his Miss Right, his dream girl, who was called Zelda. Zelda who was considered as the most beautiful and popular girl in any party, was crazy about drinking, smoking and dancing all night as well as ballet dancer and talented poet. Fitzgerald fell in love with Zelda almost at the first sight and proposed to her, regardless of the fact that his financial status couldn't satisfy her desires of luxurious lives. It was not easy for Fitzgerald to keep his relationship with Zelda until he got his first? gold in 1920. Fitzgeral and Zelda indulged in the spontaneous pleasure just like the ordinary Americans at that moment. Americans living in The Jazz Age expected to see fashionable society in Scott Fitzgerald's works, and his personal love life was as amazing as that in his works. People living in the dream must wake up one day and get what they deserve sooner or later. The Fizgeralds were not exceptional. In 1924, the Fitzgeralds moved to France, where his wife Zelda broke up with him for a French pilot. While Fitzgerald was fighting his love rival, he was busy writing The Great Gatsby, in which he depicted his emotional life. The work's success changed nothing much, for his wife was an alcoholic and an economic recession followed in the United States.

It was for The Great Gatsby that Fizgeral won the position in the history of American literature. Readers can find out the author himself and his short life through the story depicting how a young man called Gatsby from a poor family is struggling for his success. Gatsby is poor, but he has never reconciled to life in any situation, even when he was in the First World War camp. He fell in love with a beautiful from a decent family called Daisy and they broke up when Gatsby had to go to Europe. Soon after that Daisy married a playboy called Tom who was born in a rich family. When Gatsby found Daisy was living a rich and miserable life, he wanted to do something to save her and his spiritual world. By drawing Daisy's attention, Gatsby built a mansion on the opposite side of Daisy and Tom's house, inviting guests he did not know to his parties. He chose to win back Daisy's heart, regardless of the fact that Daisy was not yesterday's Daisy living in his mind. He sacrificed his life for her in the end of the story, and no one including his guests and Daisy appeared in his funeral. "On the surface, the Great Gatsby is just a picture of the Jazz Age, it makes a detailed description of all kinds of corruption phenomenon in that era....At the same time, people can also deeply feel the end of an era, the beginning of another time, the prospect of the collapse of traditional beliefs in the United States."

Existential literary was popular in Europe and the United States in the 20th century, and it developed in high top in the late $40 \mathrm{~s}$ to $50 \mathrm{~s}$. The main concept of Existentialism was respecting human individuality and freedom. During the advent of modern times, human found they were homeless, and they lost the sense of belonging, thinking they were "outsider" of human society. Under this social situation, existentialism was born. It was mainly Jean Paul Sartre's contribution that it was used in the literature. Afterwards, existentialism entered a new stage. Contemporary existentialism believed in three principles: the first was "existence precedes essence", "exist" was put before "essence". The second was "the world is absurd, life is pain". World brought human endless suffering and negative life. The third was the essence of Existentialism which was "free to 
choose". It was about the relationship between man and man. Satre said "hell is other people." Many schools of thought and postmodern literature were based on Satre's Existentialism. Many novelists applied existentialism to their works because it concerned human's lives and reflected the society.

\section{GATSBY's FREE CHOICES}

Human essence came from the process of life after they went to the world and it was reflected by their living environment and their choices. Gatsby's free choices exposed his essence. In order to seize the love of his, he was trying to enter the upper class. Satre said that "humans have the responsibility to choose what we become." When Gatsby was young, he wished to change his living condition and dreamed of being a rich man. Gatsby's grandparents had kept living in the upper-class, so his ambitious father gave Gatsby too much high expectations, which led to Gatsby's strong wish regaining his family's past glory. In order to be equal to those who was from the descent family, he chose to change his real name, made a plan and worked hard for it everyday. At age of eighteen, Gatsby chose to be close to an important man called Cody after saving his yacht. He did hope it was his turning point of life if he kept the good relationship with powerful and rich Cody. His day dream fell apart because he inherited nothing after Cody's death. By working for Cody, Gatsby's life and essence were changed. Another choice leading to his change of essence was when he met Daisy. He took risk of doing something illegal for Daisy's love, however, at last he spent his life protecting Daisy in the way of being killed by the husband of Daisy's husband's mistress. Gatsby's first love Daisy chose to marry a guy who was very rich, however, Gatsby still thought Daisy loved him. If Gatsby saw through Daisy, figuring out she was nothing but superficial, vain and shallow, he would have lived quite different life. Gatsby refused to see the true colour of Daisy and allowed himself to believe that he could get her back if he had a fortune. After that, he took various means including the illegal ones to earn money. As soon as he became as rich as he wanted to be, he built a mansion on the other side of Daisy and Tom's. One fact that Daisy was not the original Daisy in his thought almost destroyed him, for until that moment he failed to figure out that his fortune could not fill the void in the bottom of his heart. He was stuck in the illusion of love until the last moment of his life. Satre said "free choice is not once for all. It can not be finished in one time. People have to make choice constantly. As people are changing, new choices are changing." With the development of his life situation, Gatsby's choices are supposed to be changed. Anyone against it is to get what he deserves.

\section{THE ABSURD WORLD}

By the time Fitzgerald wrote The Great Gatsby, the First World War ended. After that, the United States was immersed in booming economy and abundant materials. As one of the victorious nations the Americans fully enjoyed prosperity. The old ideas were not established whereas the old ones were questioned. Traditional moral values in Jazz Age collapsed, hedonism was popular. Fitzgerald said "This is an era of miracles, art, big spenders and irony." This was an absurd era in the view of existentialism. At that time, the material was abundant, however, the sense of morality was declining. Americans started to doubt the traditional values, therefore, people were indifferent to others and loved vanity, money and extreme comfort. Pursuit for those is endless, and whenever and wherever and whatever can satisfy their needs in those aspects. The rich Gatsby invited hundreds of guests to his parties, but in the end, none of them attended his funeral. Satre said "this world is full of subjective and selfish ideas; everyone is considering pros and cons from their own interests...And the world is full of ugly things and crime, everything is absurd." The guests who used to go to Gatsby's parties did not dare to face the consequences of his death. They were afraid of any possibility of loss of their own interests. They put their profits and safety before justice. The absurd society creates the ugly people. Taking Daisy, Gatsby's dream girl for another example, she was a fairy, dressing in white the first time she appeared in the novel. She was good at artificial art and flirt, which any men coming to her found it hard to forget. She was young, ignorant and lovely, but the other side of Daisy was selfish and feigned, whose emotions were based on the material things. Daisy's ugly side of face was hidden in the absurd world. In her relationship with Gatsby, their feeling was in a sincere and hypocritical contradiction. Daisy's love in it was due to the boring life she led, and her emotion was based on the material things. As a matter of fact, Daisy had no real affections at all in that absurd world. Another uglier person is Daisy's husband, Tom Buchanan, to be exact, he was a devil. Tom had one of the most powerful body due to some physical accomplishments. Tome was a well-known celebrity and he was athletic and arrogant, with straw yellow hair, a pair of aggressive and glowing eyes on his face. He was the typical American in the Jazz Age, who made every effort to obtain wealth and honor. In The Great Gatsby, Tom Buchanan enticed Daisy and had an affair with Mrs. Wilson when the honeymoon was not over. Tom was extremely different from Gatsby in the way they loved Daisy, Tom loved himself more that he loved Daisy. He stuck with his living principal of fully enjoying himself and nothing would change that, including marriage. What's more, he used any means to achieve what he wanted. When Mrs. Wilson was struck by a car, Tom asked Daisy to shift the misfortune on Gatsby. He instigated Mr. Wilson to kill Gatsby at last. The powerful people tried to take any chance to escape punishment when they were in trouble. They made use of every method to maintain their authority and what they had. The world Gatsby lived was full of absurdity, absurd society and ugly people. The struggles and conflicts in the absurd society are inevitable. The individual fate is involved in the social environment. Just like what that proverb says "Circumstances creates heroes". Gatsby's greatness is founded 
on that day's America, however, Great Gatsby dies for his belief of love when he is unaware of the wrong timing. He is one of the people who fail to accomplish his American Dreams. Atheistic existentialists propose that humans are supposed to take actions to win the meaning of life and create their values for themselves.

\section{GATSBY's RELATIONSHIP WITH OTHER PEOPLE}

Satre said that "the look of others changes me from a free subject to a dead subject and forces me to judge myself by others", "While I attempt to free myself from the hold of the other, the other is trying to free himself from mine; while I seek to enslave the other, the other seeks to enslave me." As the story's narrator, Nick was the model of the traditional values. As a matter of fact, Gatsby and Nick were in the First Division during the war. The same experience might give them the same angels to explore the absurd world. He admired Gatsby and they had similar understanding of the world around them. Nick hated those who were hypocrisy and indifferent and thought they were rotten crowd. Nick was Daisy's distant cousin, and he could not like her, however, Gatsby used the relative relationship between Nick and Daisy to approach her easily, however, Nick respected Gatsby and he believed Gatsby was different from the people he met in the wilderness time. They became good friends. Nick was the only guest who was invited to Gatsby's party. After getting to know how young Gatsby worked for his dream, Nick had more sympathies for Gatsby's death. On the path Gatsby realized his dream, Nick made a great contribution, and however, there was no doubt that Nick's help led to Gatsby's poor fate. Nick was Gatsby's good friend and he respected Gatsby very much, but he did not escape the destiny of "hell is other people". Likewise, Nick was innocent, and Gatsby's death would damage him deep down in his heart. Great Gatsby was not exceptional, he was one of Nick's "other people". "Who is to blame?" No one can give the answer.

Daisy, the heroine of The Great Gatsby, the trouble maker, was vain, who was the source of Gatsby's tragedy. Daisy and Gatsby belonged to different classes and lived different ways of lives. She was his first love and he did everything for his young love, but she loved only money and materials. When she met Gatsby again, her love became decadent. But Gatsby was always immersed in the past and thought the richness of his could get her back. Unfortunately, Daisy was both the opener and the terminator of Gatsby's dream. Gatsby failed to understand that Daisy who he loved when he was young was the fake image he created at his youth, and his eyes deceived him. Gatsby was free and free to choose the love to Daisy, however, freedom not only included opportunity for prosperity and success and even an upward social mobility for the family which Gatsby's father did think he could get through him, but also accepted the consequence one had to face afterwards. Gatsby's wrong decision led to his tragedy. His individual failure was connected with the circumstance and the people who lived in it. Gatsby who had a great American Dream could not manage to avoid disappointment and desperation in the absurd world. Tom, Daisy's husband, was another factor that resulted in Gatsby's tragedy. He was self-centered, superficial and arrogant. As one of the greatest rugby players in New Haven, Tom had not cared too much about Gatsby at first until he found the ambiguous relationship between his wife Daisy and Gatsby. He was from a descent family, which meant a lot in the society. People from this kind of family looked down upon those from the lower class. Furthermore, he was a popular star. Tom thought he was made in the image of God and he was given the right to punish the potential foes. Afterwards, he secretly investigated Gatsby's background in order to expose his lie. In the end, Tom framed Gatsby and led to his disillusion of ultimate dream.

\section{CONCLUSION}

The Great Gatsby is a classic in the history of American literature and it is also the best work of F Scott Fitzgerald's fiction. It is translated into numerous languages and loved by readers all over the world. The Great Gatsby is appreciated by many scholars in different ways as well. Because of this work, Scott Fitzgerald becomes one of the spokesmen of the Jazz Age. Existentialism originates in the 20th and its main ideas are existence precedes essence, freedom of choice, absurdity and view of humans. From this perspective the paper attempted to study Gatsby's American dream and his tragic fate. Gatsby lost his life at early age when he was trying to realize his American dream. Gatsby is great because he does his best to follow his heart on the path to his American Dream. The great Gatsby deserves a better life and it is a pity that he is not given the chance to survive the Jazz Age. Gatsby chose to use the illegal means to be rich to win Daisy back. He is supposed to be responsible for his choices and his tragic fate. The others, like Daisy, Tom, even Dick, are supposed to take the responsibility as well. Of course, the absurd world is involved in those blames. No one is an island. Circumstances create heroes. The Jazz Age makes humble Gatsby and his creater Fizgerald great, however, they pay their precious lives for that. The price is too huge to burden. The existentialism gives the readers a wide angle to better understanding of The Great Gatsby. If life is meaningless, humans should avoid being negative. When humans enjoy the free choices, they should undertake the corresponding responsibility.

\section{REFERENCES}

[1] F Scott Fizgerald. The Great Gatsby [M]. Hertfordshire: Wordsworth Classics. 1993.

[2] Jean Paul Sartre. Being and Nothingness: an essay on phenomenological ontology [M]. Barnes, Hazel E (translator) London: Routledge, 1958.

[3] Wei Li. On Fizgerald's Novel the Great Gatsby, [J]. Journal of Suihua Normal University, 2009(9). (In Chinese)

[4] Yanan Yuan. The Interpretation of the Great Gatsby from the Perspective of Existentialism [J]. Journal of Nanchang Education Institute, 2011(8). (In Chinese)

[5] Li Ran. On Satre's Existentialism [J]. Journal of Hubei Economy Institute, 2011(8). (In Chinese)

[6] Li Tian. On the Temporary European and American Literature from the Perspective of Existentialism: Wandering between the Appreciation of the Ugly and the beautiful [J]. Shijiazhuang: The Great Wall. 2013(2). (In Chinese)

[7] Fengxia Yan. The Interpretation of Exixtentialism in Contemporary British and American Literature [J]. Journal of Heilongiiang Education Institute, 2013(9). (In Chinese) 